\title{
Evaluating the protection of wildlife in parks: the case of African buffalo in Serengeti
}

\author{
K. L. Metzger - A. R. E. Sinclair • Ray Hilborn • J. Grant C. Hopcraft • \\ Simon A. R. Mduma
}

Received: 16 July 2009/Accepted: 21 July 2010/Published online: 3 August 2010

(C) The Author(s) 2010. This article is published with open access at Springerlink.com

\begin{abstract}
Human population growth rates on the borders of protected areas in Africa are nearly double the average rural growth, suggesting that protected areas attract human settlement. Increasing human populations could be a threat to biodiversity through increases in illegal hunting. In the Serengeti ecosystem, Tanzania, there have been marked declines in black rhino (Diceros bicornis), elephant (Loxodonta africana) and African buffalo (Syncerus caffer) inside the protected area during a period when there was a reduction of protection through anti-poaching effort (1976-1996). Subsequently, protection effort has increased and has remained stable. During both periods there were major differences in population decline and recovery in different areas. The purpose of this paper is to analyse the possible causes of the spatial differences. We used a spatially structured population model to analyze the impacts of three factors-(i) hunting, (ii) food shortage and (iii) natural predation. Population changes were best explained by illegal hunting but model fit improved with the addition of predation mortality and the effect of food supply in areas where hunting was least. We used a GIS analysis to determine variation in human settlement rates and related those rates to intrinsic population changes in buffalo. Buffalo populations in close proximity to areas with higher rates of human settlement had low or
\end{abstract}

\section{K. L. Metzger $(\bowtie) \cdot$ A. R. E. Sinclair}

Centre for Biodiversity Research, University of British Columbia, 6270 University Blvd,

Vancouver, British Columbia V6T 1Z4, Canada

e-mail: metzger@zoology.ubc.ca

R. Hilborn

School of Aquatic and Fishery Sciences, University of Washington, Box 355020, Seattle, WA 98195-5020, USA

\section{J. G. C. Hopcraft}

Frankfurt Zoological Society, Serengeti National Park, Box 14935, Serengeti, Tanzania

J. G. C. Hopcraft

Arusha, Tanzania \& Community and Conservation Ecology, University of Groningen, PO Box 14, 9750AA Haren, The Netherlands 
negative rates of increase and were slowest to recover or failed to recover at all. The increase in human populations along the western boundary of the Serengeti ecosystem has led to negative consequences for wildlife populations, pointing to the need for enforcement of wildlife laws to mitigate these effects.

Keywords African buffalo - Animal monitoring data - Enforcement - Illegal hunting · Instantaneous rate of population change - Serengeti National Park

\section{Introduction}

Conservation has traditionally responded to potential loses of biota by establishing legally protected areas (Pressey 1994; Rodrigues et al. 2004). Wittemyer et al. (2008) have shown that average human population growth rates on the borders of protected areas in Africa and Latin America were nearly double the average rural growth, suggesting that protected areas attracted human settlement. People perceive or obtain benefit from their proximity to such areas (de Sherbinin and Freudenberger 1998; Scholte 2003) but, there could be a concomitant threat to biodiversity within them. Many species are continuing to decrease within protected areas (Brashares et al. 2001; Newmark 2008) often due to the illegal wildlife harvesting for meat and trophies (Milner-Gulland et al. 2003). This is particularly true for African nature reserves where local species extinctions are directly linked to human population proximity, high reserve perimeter to area ratios, and bushmeat hunting (Brashares et al. 2001; Ogutu et al. 2009).

In the Serengeti ecosystem, Tanzania, there have been marked declines in black rhino (Diceros bicornis), elephant (Loxodonta africana) and African buffalo (Syncerus caffer) inside the protected area (Dublin et al. 1990b; Metzger et al. 2007; Sinclair et al. 2007). Declines in the numbers of large herbivores were attributed to cessation of anti-poaching activities during a period of economic decline. Analysis of the trends in the buffalo population over the whole area has suggested that population change was primarily due to illegal hunting, and that enforcement of wildlife laws reduced the illegal offtake (Hilborn et al. 2006) a conclusion also reached for other areas (Hilborn et al. 2006; Jachmann and Billiouw 1997; Keane et al. 2008; Leader-Williams and Milner-Gulland 1993). Using 50 years of buffalo census data, Hilborn et al. (2006) established that illegal hunting and enforcement activities could account for the overall trends in buffalo population yet examination of the buffalo total counts indicated variation in the buffalo population recovery; some areas have almost completely recovered from the population low of 1994 and other areas have failed to recover. Therefore, the main purpose of this paper is to analyse the possible causes of these spatial differences.

Buffalo are known to be targeted by illegal hunters (Sinclair 1977). Park rangers who actively search for snares and signs of illegal hunting have identified buffalo carcasses in the field (Hilborn personal observation) and buffalo meat appears in villagers bushmeat diets (Ndibalema and Songorwa 2007). Illegal hunting remains a large threat to conservation efforts in the Serengeti (Holmern et al. 2007; Kaltenborn et al. 2005; Loibooki et al. 2002) and, therefore, we determined whether illegal hunting was a contributing factor to the spatial differences in buffalo recovery.

Many factors can contribute to variation in animal population change including disease, food supply, drought, and natural predation. Disease has been well monitored in the buffalo and we have no indication that the observed changes in population have been caused by epizootics. Rinderpest virus originally caused major declines in buffalo numbers after 1890 
but the virus has not caused declines since the 1960s (Dobson 1995; Dublin et al. 1990a; Rossiter et al. 1983; Sinclair et al. 2008), and indeed it is now globally extinct (Normille 2008). Bovine tuberculosis (Myobacterium bovis), although prevalent in South Africa (Cross et al. 2009), has not been found in Serengeti buffalo (Cleaveland et al. 2008; Sinclair 1977). Drought can be a major controlling factor and drought induced mortality occurred in 1993 causing approximately $40 \%$ mortality in the buffalo population. This mortality was equally distributed across the ecosystem and therefore cannot be responsible for the spatial patterns in recovery (Dublin et al.1990a; A. Sinclair unpublished data). While it is possible that other factors may contribute to the spatial variation of buffalo recovery, the major controlling factors are likely to be food supply, natural predation and illegal hunting. We analyzed the impacts of these three factors-hunting, food supply and natural predation-using a spatial analysis to separate out their effects. Thus, human population density and rate of increase, which we show are related to hunting within the reserve (Campbell and Hofer 1995; Hofer et al. 2000), are greatest in the west and northwest. In contrast, food limitation, which is a function of rainfall (Sinclair 1977), is most severe in the east and south, while predation is evenly spread over the buffalo range. The greatest food supply is in the north where rainfall is highest (Fig. 1). The next highest food levels are in the west, while the lowest food supplies are in the east (Sinclair 1977). During the 1960s, prior to the population collapse, these northern areas supported the highest densities of buffalo recorded in Africa, and in general Serengeti buffalo are limited by food and not by predation (Sinclair 1977).

\section{Materials and methods}

\section{Study area}

The Serengeti-Mara ecosystem is located east of Lake Victoria and northwest of the Ngorongoro highlands and the Rift Valley (Fig. 1) and is described elsewhere (Sinclair and Arcese 1995b; Sinclair et al. 2007; Sinclair and Norton-Griffiths 1979). Serengeti National Park is designated IUCN land category II and is managed for ecosystem protection and recreation. A network of game reserves and conservation areas are located to the west and east of Serengeti National Park (Fig. 1). This whole area is known as the Greater Serengeti Ecosystem. The east of the national park boundary is settled by Maasai pastoralists who rarely hunt for wild meat and their lifestyles tend to be consistent with conservation of wildlife (Polansky et al. 2008). In contrast, human settlements to the west of the park boundary do consume game meat regularly (Holmern et al. 2006; Loibooki et al. 2002; Nyahongo et al. 2005).

\section{Buffalo total counts}

Beginning in the early 1960s, buffalo populations were censused by aerial survey every few years. A detailed description of methods is given in Sinclair (1977). In 1970 all observations of buffalo (individuals and herds) in the Greater Serengeti Ecosystem were plotted on a map of the ecosystem. These observations were later incorporated into a GIS using the Universal Transverse Mercator (UTM) coordinates. From the 1992, 1998, 2000, 2003, and 2008 censuses similar data were obtained using global positioning system (GPS) technology. The buffalo population was close to its maximum in 1970 and this census was 


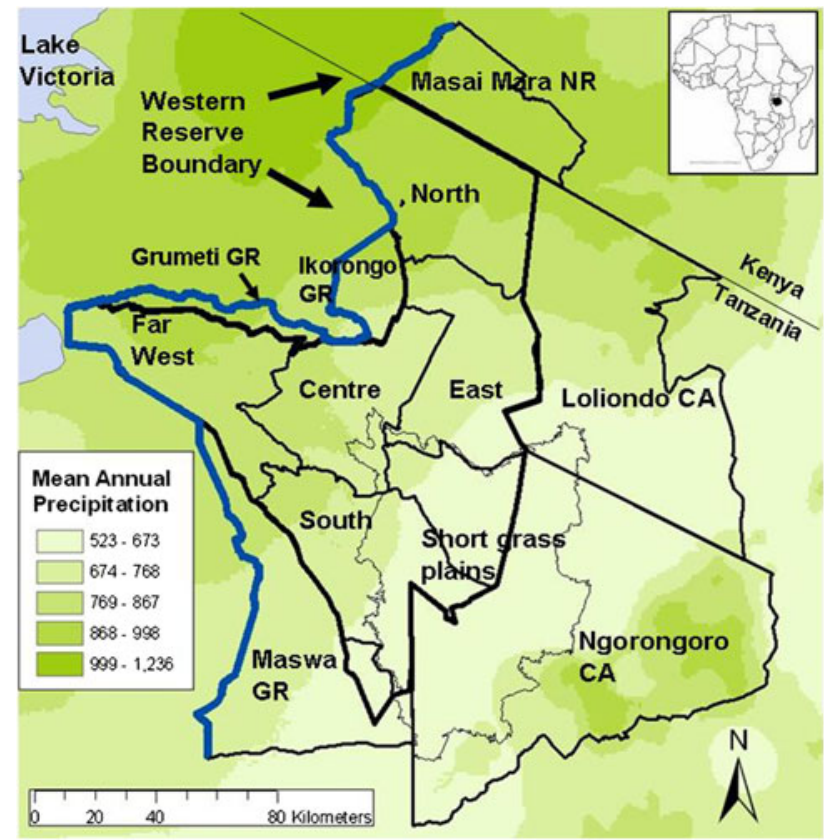

Fig. 1 The Serengeti ecosystem in Tanzania, East Africa includes the Serengeti National Park as a protected area, and the game reserves and conservations areas. These are the Ikorongo Game Reserve, Grumeti Game Reserve, Maswa Game Reserve, Ngorongoro and Loliondo Conservation Areas, which surround Serengeti National Park and have restrictions on settlement within their borders. The Serengeti National Park is divided up into zones (north, far west, centre, far east and south). Rainfall isohyets, showing the highest rainfall in the northwest and the lowest in the southeast. Rainfall data collected at local rainfall stations across the Serengeti ecosystem has been interpolated to produce the isohyets

therefore used as the baseline with which we compared the following years. We determined the instantaneous rate of change in the buffalo population from 1970 to 2008 by zone. Zones within the park (Fig. 1) represent distinct geographical and ecological areas. Buffalo herds are relatively sedentary, confine themselves to a home range of less than $20 \mathrm{~km}$ in diameter, and so rarely cross over zone boundaries (Sinclair 1977). These zones were the north, far east, far west, center, south and short grass plains. Because buffalo do not use the short grass plains we did not include this area in our analysis. We summed buffalo numbers within each zone for each year that we had census data and compared these numbers with those in 1970 to show the relative change. A major drought in 1993 affected all zones and caused a 40\% mortality (Sinclair et al. 2007, 2008).

Spatial population dynamics model

We used a spatially structured population dynamics model to determine the trends in buffalo abundance in the five different regions between 1965 and 2008 (Hilborn et al. 2006). We examined a range of possible influences on abundance. These factors included carrying capacity, which is a function of size of zone times rainfall (a surrogate for food supply, Sinclair and Arcese 1995a), lion predation, and hunting effort. The population $\hat{N}_{a, y}$, the predicted number of buffalo in zone $a$ year $y$ is given by; 


$$
\hat{N}_{a, y+1}=\left[\hat{N}_{a, y}+r \hat{N}_{a, y}\left(1-\frac{\hat{N}_{a, y}}{k_{a}}\right)\right] S_{y}-u_{a, y} \hat{N}_{a, y}-E_{a, y}
$$

while

$$
u_{a, y}=q v_{a} P_{y}
$$

and

$$
E_{a, y}=\hat{N}_{a, y}\left[1-\exp \left(z L_{y}\right)\right]
$$

where $r$ is an intrinsic rate of growth assumed to be the same in all zones. Carrying capacity for zone $a$ is $k_{a}$ and $S_{y}$ is survival from drought in year $y$, assumed to be 1.0 for all years except 1993, the year of the drought. The exploitation rate from hunting in zone $a$ and year $y$ is $u_{a}, P_{y}$ is the relative hunting effort in year $y, v_{a}$ is the relative hunting effort for zone $a$, and $q$ is a scalar relating hunting effort and area specific vulnerability to the exploitation rate. $E_{a y}$ is the number of buffalo in zone $a$ killed by lions in year $y, L_{y}$ is an index of the number of lions in buffalo habitat in year $y$, and $z$ scales the lion abundance index to lion mortality rate.

We explored a range of nested models, in various configurations that either included or excluded hunting, lion predation, and rainfall. We estimated the parameters using census data for each of five zones assuming a lognormal likelihood

$$
L\left(N_{a, y} \mid \text { parameters }\right)=\frac{1}{\sigma \sqrt{2 \pi}} \exp \left(-\frac{\left[\ln \left(N_{a, y}-\hat{N}_{a, y}\right)\right]^{2}}{2 \sigma^{2}}\right)
$$

where $N_{a y}$ is the observed number of buffalo in zone $a$, year $y$, and $\sigma$ the standard deviation of the lognormal observation process.

The relative hunting effort $(P)$ is poachers arrested per number of patrols day ${ }^{-1}$ (see Hilborn et al. 2006. Figure 1b). The zone specific vulnerability parameters $\left(v_{a}\right)$ were estimated relative to that in the north which was fixed at 1.0. The parameter $q$ is the harvest rate per unit of hunting effort $(P)$ in a zone with $v=1$.

Food supply and rainfall

We also considered a range of hypotheses regarding carrying capacity. First, we assumed all zones had the same carrying capacity. Secondly, we assumed that carrying capacity in each zone $\left(k_{a}\right)$ was proportional to the size of the zone and the rainfall. Thus,

$$
k_{a}=p A_{a} R_{a}
$$

where $A_{a}$ is the area in square $\mathrm{km}$ of zone $a, R_{a}$ is the average dry season rainfall in zone $a$, and $p$ is a scalar to relate the product of area and rainfall to the carrying capacity.

While rainfall was the primary determinant of the food supply in most of Serengeti (Fig. 1), the far east differed by lacking riverine grassland. In this zone rainfall was less suitable as a predictor of resources (Sinclair 1977). Hence, thirdly we estimated the carrying capacity for each zone independent of its size and rainfall.

Intrinsic rate of increase and lion predation

While we could, in theory, estimate the intrinsic rate of increase $(r)$ from the spatial data using the likelihood in Eq. 2 we found that the estimates obtained in that fashion were much lower than the total population growth rate in the 1960s and 1970s. This is because 
the variability of the data by zone is much higher than the variability for the total population. We estimated the intrinsic rate of increase $(r=0.092)$ from the total census between 1965 and 1976. We fixed $r$ in all scenarios except that when lion predation was added we needed to increase the $r$ value to account for additional lion mortality

$$
r=0.092+\left[1-\exp \left(z L_{1958}\right)\right]
$$

Each model scenario included different parameters estimated or fixed. In all cases we estimated the number of buffalo in each zone in the first year, and the parameter $\sigma$. Thus, the simplest model has 6 parameters, plus a single carrying capacity $(k)$ for a total of 7 parameters. As $r$ is fixed in all models it is not considered an estimated parameter.

Fine scale buffalo population rate of increase (1970-1998 and 2000-2008)

The spatial trend in buffalo population was examined by comparing two time periods; 1970-1992 and 2000-2008 by creating a fine resolution map of buffalo population change across the park. To do this we first constructed a buffalo density map. In the GIS we divided the Serengeti National Park into $5 \times 5 \mathrm{~km}$ areas and all observations within each $25 \mathrm{~km}^{2}$ area were summed. These numbers were then transformed to density (animal $\mathrm{km}^{-2}$ ) within each $25 \mathrm{~km}^{2}$ area. In order to smooth across the $25 \mathrm{~km}^{2}$ cell boundary the whole park was subdivided into $1 \mathrm{~km}^{2}$ units. The 30 nearest neighbor $1 \mathrm{~km}^{2}$ cells were averaged for each $1 \mathrm{~km}^{2}$ cell using the neighborhood analysis tool in ArcGIS 9.2. This allowed us to reduce the heterogeneity created from the clumping effect of large herds in some grid cells adjacent to empty cells. The $30 \mathrm{~km}^{2}$ area was of a similar magnitude to the maximum home range of buffalo (Sinclair 1977). We calculated the instantaneous rate of population change per year $(r)$ using the raster calculator tool in ArcGIS 9.2 spatial analyst. Instantaneous rate of population change is defined as:

$$
r=\ln \left(N_{t} / N_{0}\right) / t
$$

where $N_{t}$ is the population size at time $t, N_{O}$ is the population size at the start of the time period, and $t$ is the number of years between the two. The $r$ calculation was performed on each cell in the density map for the two time periods 1970-1992 and 2000-2008.

\section{Relation between buffalo numbers and human densities}

We calculated the distance of each buffalo observation to the nearest edge of the park where there was human settlement in 1970, 1992, 1998, 2000, 2003 and 2008. Using Pearson's correlation coefficient we determined the spatial correlation between buffalo counts and distance to humans (see below).

\section{Hunter population estimates}

We used two years of human census data, 1978 and 2002 (Bureau of Statistics, Dar es Salaam) for the area west of the Serengeti National Park boundary to Lake Victoria. Census data were organized by local areas called wards (similar to US counties). The area $\left(\mathrm{km}^{2}\right)$ of each ward was known and we converted the ward population to density (humans $\mathrm{km}^{-2}$ ). From the human density we calculated the hunter density. Hunter density is a proportion of human density, which changes with the distance from the protected area boundary. The equation is that given in Campbell and Hofer (1995). For each ward, we determined the instantaneous rate of change of hunter density between 1978 and 2002. 
Fig. 2 Buffalo population trends for the Serengeti National Park. Data from Sinclair et al. (2007)

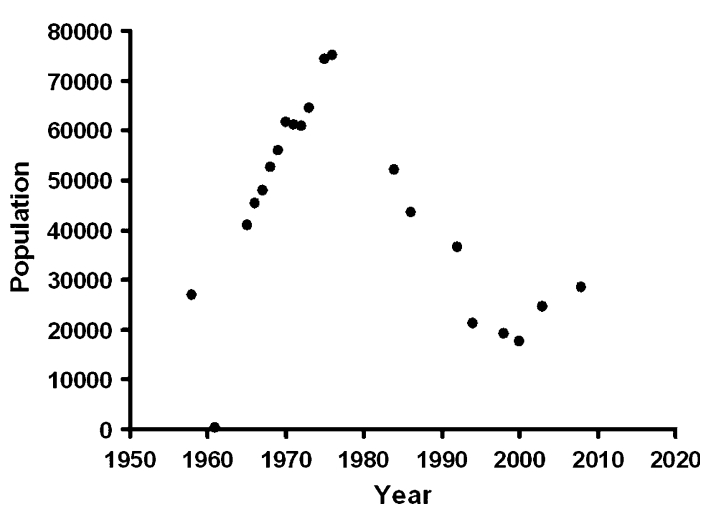

\section{Results}

Total population numbers of buffalo in the protected area

Figure 2 shows the changes in total numbers of buffalo in the Serengeti National Park since 1965. At that time the population was recovering from the impacts of the viral disease, rinderpest, and numbers subsequently increased to a peak of 74,237 in 1975 (Sinclair 1977). Shortly after that, in 1977, anti-hunting activities were severely restricted by an economic crisis in Tanzania (Hilborn et al. 2006; Sinclair and Arcese 1995b) and widespread hunting on this species (and others) followed (Dublin et al. 1990a). By 1992 anti-hunting efforts had returned but the population had been reduced to 36,119 animals, some $49 \%$ of the peak number. The sharp decline to 21,186 buffalo in 1994 reflects the effect of a severe drought amounting to an additional mortality of $42 \%$ of the remaining population. Since 1998 the population has slowly increased. The most recent census (2008) of buffalo recorded 28,524 individuals in Serengeti National Park. Because these are total counts there are no sampling errors associated with the data. However, bias errors have been calculated, accommodated by technique design and kept constant over the years (Mduma and Hopcraft 2008; Sinclair 1972).

\section{Buffalo population trends by region}

Figure $3 \mathrm{a}, \mathrm{b}$ presents the distribution of buffalo herds in 1970 before the main hunting period, and in 2003 during the recovery phase. These show that northern and western parts of the protected area have lost herds while the center and east have developed larger herds. Figure 4 shows the proportional changes in buffalo population in each zone (see Fig. 1), relative to 1970, the year when we have complete spatial distribution of animals prior to the onset of hunting. By 1992 the north had lost 84\% ( $\pm 5 \%(95 \% \mathrm{CL}))$ the far west some $38 \%( \pm 9 \%)$ and the center $29 \%( \pm 7 \%)$ of their numbers. In contrast, the south had lost $23 \%( \pm 10 \%)$ and the far east only $12 \%( \pm 6 \%)$ of the population. Since the drought of 1993, the south has increased above the 1970 level $(120 \% \pm 3 \%)$ and the far east is at $62 \%$ $( \pm 6 \%)$ of those levels. The far west and center, although just beginning to recover by 2008 , are still only at $54 \%( \pm 9 \%)$ and $40 \%( \pm 8 \%)$ of their original numbers. The northern population has been unable to recover at all and remains at a mere $2 \%( \pm 0.3 \%)$ of original numbers. In summary, the three regions with western borders had consistently lower recovery throughout the period 1970-2008 than the east and south. 

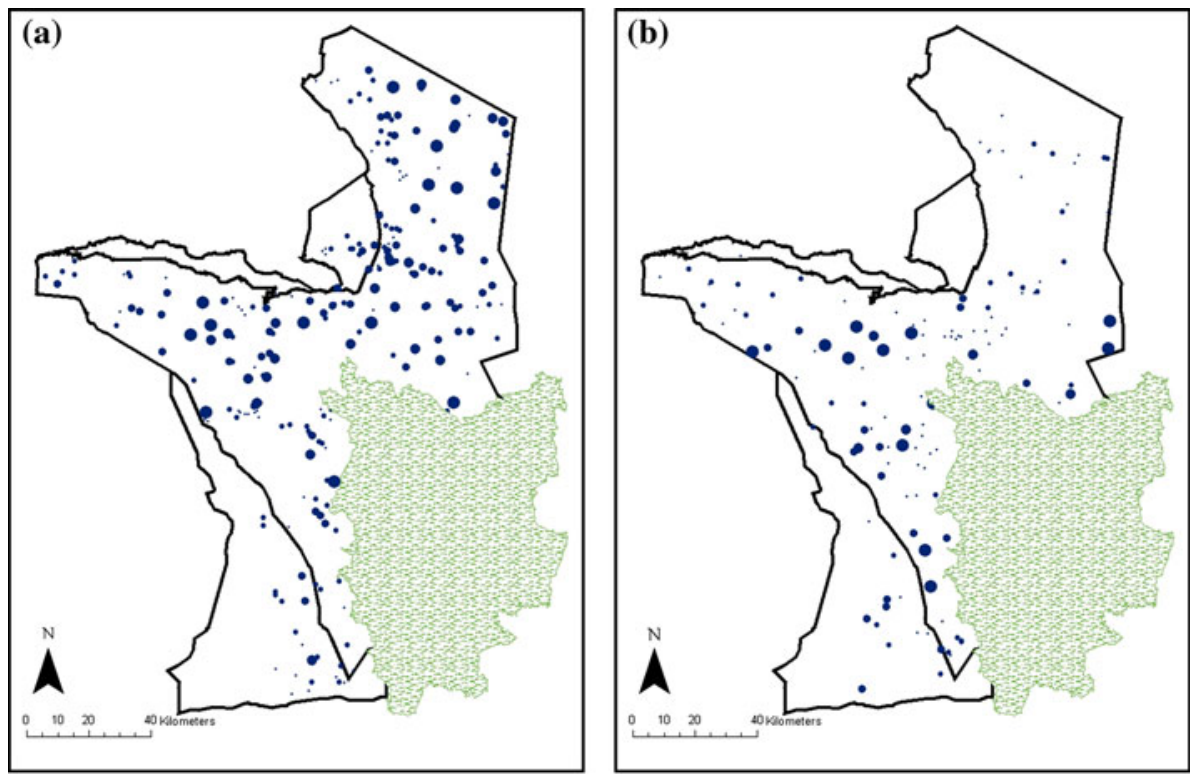

Fig. 3 The location of all buffalo herds in the park-wide censuses of (a) 1970, and (b) 2008 showing the loss of herds in the north and far west. Data from Sinclair (1977), S. A. R. Mduma unpublished. Dots represent the size of the buffalo herds at each location. The largest dot represents the largest herd at 2,800 individuals and the smallest a single buffalo

\section{Spatial population dynamics model}

Details of the model (Eq. 1) can be found in Table 1. In our basic model configuration we assumed that the carrying capacity of a zone was proportional to the area and rainfall (Eq. 3). The second model included the same hunting effort in each zone of the park with no lion predation and no drought. The third model included lion predation (Eq. 5) but no hunting effort and no drought effect. These first three models fitted the data poorly. In model 4 hunting differed in each zone but had no lion predation and the fit of the model improved greatly. Model 5 was similar to model 4 but included the mortality from the 1993 drought (Eq. 1) and again the fit of the model improved. In model 6 we allowed the carrying capacity in the far east to be different from that of other areas (for the reasons explained above that resources differed), and this provided another significant improvement in fit. Again building on model 6, in model 7 we included the impact of lion predation and this too provided an improvement. Thus, the model incorporating unequal hunting effort, survival rates resulting from drought, carrying capacity in the far east estimated separately, and lion predation provided the best fit to the census data (Fig. 4). Using the likelihood ratio model 7 would be the preferred model.

Final model parameter estimates

The model that explained the most variation in population across the zones was model 7 (Fig. 5). Using this model we estimated that the north had the highest intensity of hunting with the exploitation rate in 1982 (the worst year for hunting) being $31 \%$. The far west had the second highest hunting being $16 \%$ in 1982 , while the far east was estimated to have 
Fig. 4 Proportional changes in buffalo population in the five zones of the Serengeti at different times relative to the starting number in 1970 . Ninety-five percent confidence intervals were calculated (largest was $0.12 \%$ ) but were too small to show

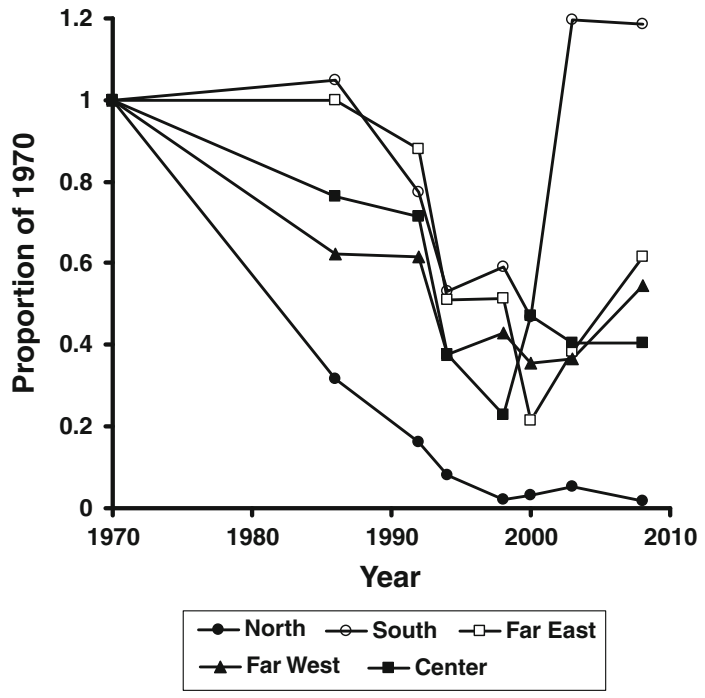

Table 1 Candidate models of buffalo population changes over the last 50 years in the five regions of the Serengeti

\begin{tabular}{|c|c|c|c|c|}
\hline Model & Model description & $\operatorname{NegLL}{ }^{\mathrm{a}}$ & \# Parameters & $A I C c$ \\
\hline 1 & Equal $k$ in all zones, no hunting, lions or drought & 91.9 & 7 & 200.2 \\
\hline 2 & Equal $k$, equal hunting in all zones, no lions or drought & 75.8 & 8 & 170.7 \\
\hline 3 & Equal $k$, lion predation, no hunting or drought & 77.9 & 8 & 174.9 \\
\hline 4 & $\begin{array}{l}\text { Equal } k \text {, hunting different by zone ( } v_{\mathrm{a}} \text { estimated), } \\
\text { no lions or drought }\end{array}$ & 37.1 & 12 & 105.6 \\
\hline 5 & $\begin{array}{l}\text { Equal } k \text {, hunting different by zone ( } v_{\mathrm{a}} \text { estimated), } \\
\text { drought included (S1993 estimated), no lions }\end{array}$ & 16.0 & 13 & 66.8 \\
\hline 6 & $\begin{array}{l}K \text { different for far east, hunting different by zone } \\
\text { ( } v_{\text {a }} \text { estimated), drought included (S1993 estimated), } \\
\text { no lions }\end{array}$ & 13.7 & 14 & 65.9 \\
\hline 7 & $\begin{array}{l}K \text { different for far east, hunting different by zone } \\
\text { ( } v_{\text {a }} \text { estimated), drought included (S1993 estimated), } \\
\text { lion predation included }\end{array}$ & 10.7 & 15 & 63.7 \\
\hline
\end{tabular}

${ }^{\text {a }}$ NegLL negative log likelihood

The models are defined by the variables that drive population dynamics. The best model (lowest NegLL) is shown in bold

zero hunting mortality (Table 2). In addition, the carrying capacity in the far east was not adequately estimated from area and rainfall, and so was estimated independently in model 7. Lion predation rate was estimated to be $10 \%$ (assumed constant in all areas), and the 1993 drought mortality was estimated to be $48 \%$.

Fine-scale analysis of buffalo and human population changes

The fine scale spatial analysis produced a gradation in the rates of buffalo population increase (Fig. 6) during the hunting period (1970-1992). There were negative rates of 

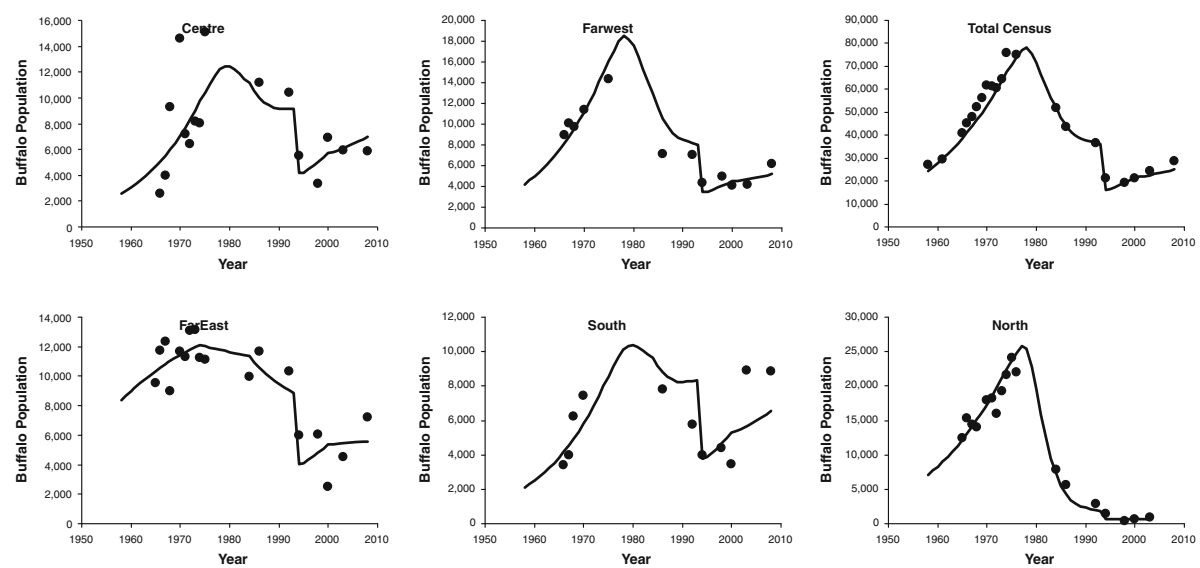

Fig. 5 Observed abundance of African buffalo (dots) and model predictions (solid line) for the zones of the Serengeti and for the total population

increase in the northwest and positive rates of increase in the east and south. The far west was more complex but rates of increase were still lower there than in the east.

A similar pattern (Fig. 7a) is exhibited during the increase phase (1998-2008) with population decreases in the northwest and west and population increases in the east. In the increase phase, the areas of population decreases were more concentrated and restricted to the northwest and west of the park compared to the hunting phase. While there were areas in the western corridor that still exhibited population decreases the area south of Grumeti Game Reserve shows population increases compared to the hunting phase.

This pattern of buffalo population growth is the converse of the human population growth adjacent to the protected area (Fig. 7b). Hunters living within $40 \mathrm{~km}$ of the protected area were estimated as 20,000 in 1973 and 36,000 in 2002. The instantaneous rate of increase was 0.03 per year, similar to the national average. Numbers within $10 \mathrm{~km}$ of the protected area increased from 13,000 to 24,000 , a similar rate of change (3\% per year). However, the population adjacent to the northwest border of the park has increased at a faster rate (4.4\% per year) mostly through immigration (Campbell and Hofer 1995). In 1978 human population densities varied ranging from $0.1-954$ people $\mathrm{km}^{-2}$ and in 2002 the range in densities spanned $15-2,840$ people $\mathrm{km}^{-2}$.

Buffalo increase and distance to reserve boundary

In 1970, prior to the decrease phase there was no spatial relationship between buffalo occupancy and distance to the reserve boundary. During the hunting phase there was a positive relationship between distance and buffalo numbers $(1992, r=0.15, P$-value $<$ 0.001 , and $1998 r=0.23, P$-value $=0.03)$. When enforcement was increased (2000-2008) there was no relationship between distance and buffalo.

\section{Discussion}

Our results explain the spatial variation in buffalo population recovery across the protected area and elaborate on the work of Hilborn et al. (2006), which confined itself to the time 
Table 2 Final 'best' model parameter estimates that predict population changes for the five different regions ( $\mathrm{L}$ was $10 \%$ for the final model). Hunting was greatest in the North zone

\begin{tabular}{llll}
\hline & $k$ & $\begin{array}{l}\text { Hunting mortality } \\
\text { in 1978 }\end{array}$ & $\begin{array}{l}\text { Average lion } \\
\text { mortality rate (\%) }\end{array}$ \\
\hline North & $\infty$ & 0.31 & 10 \\
Far west & $\infty$ & 0.16 & 10 \\
Centre & $\infty$ & 0.11 & 10 \\
Far east & 24,999 & 0.00 & 10 \\
South & $\infty$ & 0.10 & 10 \\
\hline
\end{tabular}

Fig. 6 Fine scale spatial differences in the rate of population change 1970-1992 showing the greatest loss in the north and far west. Dark areas represent negative population increases and light areas represent higher values $(r=-0.3$ to +0.05$)$

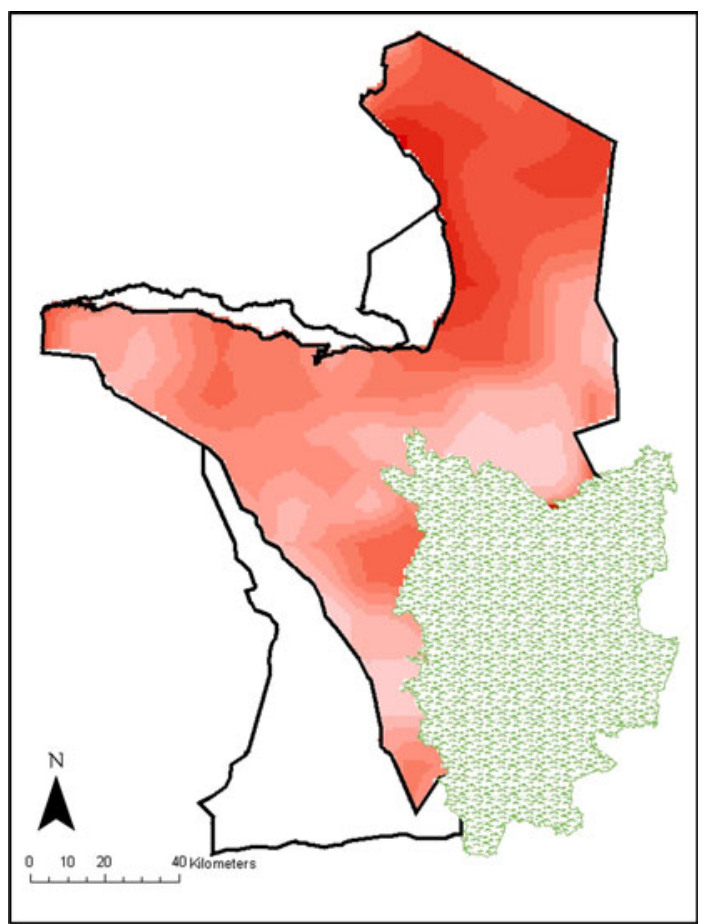

trends of the whole buffalo population. Buffalo population changes are best explained largely by hunting but model fit was improved with the addition of predation mortality. Food supply was only a factor in areas where hunting was least, namely the east and south. In addition, our spatial results are consistent with the trends in the elephant population (Sinclair et al. 2007, 2008). Elephants behave more as one cohesive population, which moves away from disturbed areas and finds sanctuary in more peaceful areas, so that densities are a reflection of movements.

Buffalo on the other hand are extremely philopatric and remain within their home range irrespective of the disturbance (Sinclair 1977). Therefore, buffalo numbers reflect the local dynamics of an area. The buffalo populations in close proximity to areas with higher rates of human settlement had low or negative intrinsic rates of population increases and, therefore, were either slowest to recover or failing to recover at all. Areas of slow buffalo recovery are consistent with the previous analysis by Campbell and Hofer (1995), which identified similar areas of high human exploitation on a different suite of species, namely the resident antelopes. Hunter populations reside along the western and north-western 

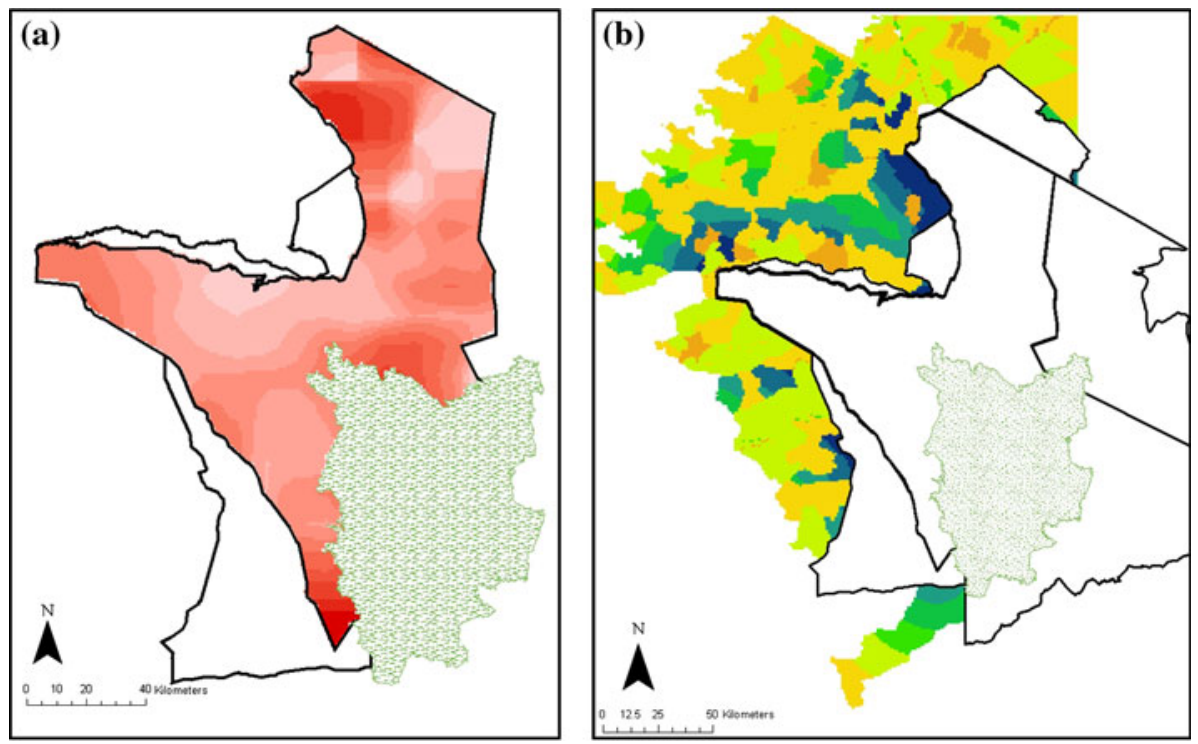

Fig. 7 (a) Fine scale spatial differences in the rate of population change 2000-2008 showing the slowest increase in the north and far west. Dark areas represent negative population increases and light areas represent higher values $(r=-0.9$ to +0.48$)$. (b) Instantaneous rate of population change of hunter population densities to the west of Serengeti National Park. Dark areas represent high population growth whereas light areas represent low population growth $(r=-0.6$ to +0.59$)$. Location of fastest increase is adjacent to areas of slowest increase in buffalo seen in Fig. 7a

boundaries of the protected area, and incursions are made into the park from the west. Human populations have increased considerably in the past 30 years (Fig. 7b) and buffalo numbers in the north and the far west reflect these changes in human populations along the boundaries. In contrast, the strong gradient in food supply, which is determined by the rainfall gradient (Fig. 1), is opposite to the trends in population recovery, i.e. areas of high food supply are those with the least recovery.

In conclusion, the increase in human populations along the western boundaries of the Serengeti ecosystem has led to negative consequences within the protected area on wildlife populations, as indicated by trends in the buffalo population. This result is consistent with the predicted impacts from increases of human settlement around protected areas elsewhere in Africa (Harcourt et al. 2001; Wittemyer et al. 2008). Hilborn et al. (2006) suggested that these negative consequences are mitigated by increases in enforcement of wildlife laws by protected area authorities.

Acknowledgments This work was made possible by the contribution of data from many sources; International Livestock Research Institute provided the Kenya human population data, M. Loibooki provided the Tanzanian human population census data, the Tanzania Wildlife Research Institute and the Frankfurt Zoological Society permitted us to use the current animal census data. We are grateful to Tanzania National Parks and Tanzania Wildlife Research Institute for their continued support of the Serengeti Biodiversity Program. This work has been funded by the Natural Sciences \& Engineering Research Council of Canada and the Frankfurt Zoological Society.

Open Access This article is distributed under the terms of the Creative Commons Attribution Noncommercial License which permits any noncommercial use, distribution, and reproduction in any medium, provided the original author(s) and source are credited. 


\section{References}

Brashares JS, Arcese P, Sam MK (2001) Human demography and reserve size predict wildlife extinction in West Africa. Proc R Soc Lond, Ser B: Biol Sci 268:2473-2478

Campbell K, Hofer H (1995) People and wildlife: spatial dynamics and zones of interaction. In: Sinclair ARE, Arcese P (eds) Serengeti II: dynamics, management and conservation of an ecosystem. University of Chicago Press, Chicago, pp 534-570

Cleaveland S, Packer C, Hampson K, Kaare M, Kock R, Craft M, Lembo T, Mlengeya T, Dobson A (2008) The multiple roles of infectious diseases in the Serengeti ecosystem. In: Sinclair ARE, Packer C, Mduma SAR, Fryxell JM (eds) Serengeti III: human impacts on ecosystem dynamics. University of Chicago Press, Chicago, pp 209-239

Cross PC, Heisey DM, Bowers JA, Hay CT, Wolhuter J, Buss P, Hofmeyr M, Michel AL, Bengis RG, Bird TLF, DuToit JT, Getz MW (2009) Disease, predation and demography: assessing the impacts of bovine tuberculosis on African buffalo by monitoring at individual and population levels. J Appl Ecol 46:467-475

de Sherbinin A, Freudenberger M (1998) Migration to protected areas and buffer zones: can we stem the tide? Parks 8:38-53

Dobson A (1995) The ecology and epidemiology of rinderpest virus in Serengeti and Ngorongoro conservation area. In: Sinclair ARE, Arcese P (eds) Serengeti II: dynamics, management, and conservation of an ecosystem. University of Chicago Press, Chicago, pp 474-485

Dublin HT, Sinclair ARE, Boutin S, Anderson E, Jago M, Arcese P (1990a) Does competition regulate ungulate populations? further evidence from Serengeti, Tanzania. Oecologia 82:283-288

Dublin HT, Sinclair ARE, McGlade J (1990b) Elephants and fire as causes of multiple stable states in the Serengeti-Mara woodlands. J Anim Ecol 59:1147-1164

Harcourt AH, Parks SA, Woodroffe R (2001) Human density as an influence of species/area relationships: double jeopardy for African reserves? Biodivers Conserv 10:1011-1026

Hilborn R, Arcese P, Borner M, Hando J, Hopcraft G, Loibooki M, Mduma S, Sinclair ARE (2006) Effective enforcement in a conservation area. Science 314:1266

Hofer H, Campbell KL, East ML, Huish SA (2000) Modeling the spatial distribution of the economic costs and benefits of illegal game meat hunting in the Serengeti. Nat Resour Model 13:151-177

Holmern T, Mkama S, Muya J, Roskaft E (2006) Intraspecific prey choice of bushmeat hunters outside the Serengeti National Park, Tanzania; a preliminary analysis. Afr Zool 41:81-87

Holmern T, Muya J, Roskaft E (2007) Local law enforcement and illegal bushmeat hunting outside the Serengeti National Park, Tanzania. Environ Conserv 34:55-63

Jachmann H, Billiouw M (1997) Elephant poaching and law enforcement in the central Luangwa Valley, Zambia. J Appl Ecol 34:233-244

Kaltenborn BP, Nyahongo JW, Tingstad KM (2005) The nature of hunting around the Western Corridor of Serengeti National Park. Eur J Wildl Resour 51:213-222

Keane A, Jones JPG, Edwards-Jones G, Milner-Gulland EJ (2008) The sleeping policeman: understanding issues of enforcement and compliance in conservation. Anim Conserv doi:10.111/j.1469-1795. 2008.00170x

Leader-Williams N, Milner-Gulland EJ (1993) Policies for the enforcement of wildlife laws: the balance between detection and penalties in Luangwa Valley, Zambia. Conserv Biol 7:611-617

Loibooki M, Hofer H, Campbell KLI, East ML (2002) Bushmeat hunting by communities adjacent to the Serengeti National Park, Tanzania: the importance of livestock ownership and alternative sources of protein and income. Environ Conserv 29:391-398

Mduma SAR, Hopcraft JGC (2008) The main herbivorous mammals and crocodile in the Greater Serengeti Ecosystem-appendix. In: Sinclair ARE, Packer C, Mduma SAR, Fryxell JM (eds) Serengeti III: human impacts on ecosystem dynamics. Chicago University Press, Chicago

Metzger KL, Sinclair ARE, Campbell KLI, Hilborn R, Hopcraft JGC, Mduma SAR, Reich RM (2007) Using historical data to establish baselines for conservation: the black rhinoceros (Diceros bicornis) of the Serengeti as a case study. Biol Conserv 139:358-374

Milner-Gulland EJ, Bennett EL, Group SACWM (2003) Wild meat-the bigger picture. Trends Ecol Evol 18:351-357

Ndibalema V, Songorwa N (2007) Illegal meat hunting in Serengeti: dynamics in consumption and preferences. Afr J Ecol 46:311-319

Newmark WD (2008) Isolation of African protected areas. Front Ecol Environ 6:321-328

Normille D (2008) Driven to extinction. Science 319:1606-1609

Nyahongo JW, East ML, Mturi FA, Hofer H (2005) Benefits and costs of illegal grazing and hunting in the Serengeti ecosystem. Environ Conserv 32:326-332 
Ogutu JO, Piepho HP, Dublin HT, Bhola N, Reid RS (2009) Dynamics of Mara-Serengeti ungulates in relation to land use changes. J Zool 278:1-14

Polansky S, Schmitt J, Costello C, Tajibaeva L (2008) Larger-scale influences on the Serengeti Ecosystem: national policy, economics, and human demography. In: Sinclair ARE, Packer C, Mduma SAR, Fryxell JM (eds) Serengeti III: human impacts on ecosystem dynamics. Chicago University Press, Chicago

Pressey RL (1994) Ad hoc reservations: forward or backward steps in developing representative reserve systems? Conserv Biol 8:662-668

Rodrigues ASL, Andelman SJ, Bakarr MI, Boitani L, Brooks TM, Cowling RM, Fishpool LDC, deFonseca GAB, Gaston KJ, Hoffman MT, Long JS, Marquet PA, Pilgrim JD, Pressey RL, Schipper J, Sechrest W, Stuart SN, Underhill LG, Waller RW, Watts MEJ, Yan X (2004) Effectiveness of the global protected area network in representing species diversity. Nature 428:640-643

Rossiter PB, Jessett DM, Wafula JS, Karstad L, Chema S, Taylor WP, Rowe L, Nyamge JC, Otaru M, Mumbala MGR (1983) Re-emergence of rinderpest as a threat in East Africa since 1979. Vet Rec 113:459-461

Scholte P (2003) Immigration: a potential time bomb under the integration of conservation and development. Ambio 32:58-64

Sinclair ARE (1972) Long term monitoring of mammal populations in the Serengeti: census of non-migratory ungulates, 1971. East Afr Wildl J 10:287-297

Sinclair ARE (1977) The African buffalo. University of Chicago Press, Chicago

Sinclair ARE, Arcese P (1995a) Population consequences of predation-sensitive foraging: the Serengeti wildebeest. Ecology 76:882-891

Sinclair ARE, Arcese P (eds) (1995b) Serengeti II: dynamics, management and conservation of an ecosystem. University of Chicago Press, Chicago

Sinclair ARE, Norton-Griffiths M (eds) (1979) Serengeti-dynamics of an ecosystem. University of Chicago Press, Chicago

Sinclair ARE, Mduma SAR, Hopcraft JGC, Fryxell JM, Hilborn R, Thirgood S (2007) Long-term ecosystem dynamics in the Serengeti: lessons for conservation. Conserv Biol 21:580-590

Sinclair ARE, Hopcraft JGC, Olff H, Mduma SAR, Galvin KA, Sharam GJ (2008) Historical and future changes to the Serengeti ecosystem. In: Sinclair ARE, Packer C, Mduma SAR, Fryxell JM (eds) Serengeti III: human impacts on ecosystem dynamics. Chicago University Press, Chicago

Wittemyer G, Elsen P, Bean WT, Coleman A, Burton O, Brashares JS (2008) Accelerated human population growth at protected area edges. Science 321:123-126 